\title{
Body Movements During Sleep as an Indicator of Comfort
}

\author{
Mikie Kusunoki \\ Department of Hygiene, School of Medicine, Hiroshima University, Hiroshima
}

\section{INTRODUCTION}

Man spends about one third of his life in bed, so it is therefore important for us to pay close attention to the surfaces on which we occupy so much of our time. When studying mattresses it is necessary to consider both the physical properties of the material as well as psychological factors such as the comfort of the sleeper. It is unfortunate that science has given so little attention to these psychological factors. According to Belart ${ }^{11}$, there are three requirements that apply to mattresses on medical grounds ; comfort when lying down, good heat retention and adequate absorption of perspiration. Belart and another researcher, Grandjean ${ }^{2}$ said that comfort when lying down was especially important and should be taken up experimentally. Comfort is a complex phenomenon and experiments investigating it have not shown any decisive results to date. Moreover a research methodology for assessing and interpreting comfort has yet to be set up. When formulating a measurement index for comfort, an objective indicator is necessary. Mattresses are an integral part of sleep, therefore a suitable objective indicator must reflect the various elements and quality of sleep. To date the study of sleep quality has chiefly dealt with the field of physiology. In these studies ${ }^{3 \sim 7)}$ all-night recordings have been made using a electroencephalograph (EEG). However, as EEG recording necessitates the use of a laboratory and the attachment of electrodes and wires, the recordings might not provide an accurate assessment of the subject's usual sleep pattern ${ }^{8,9)}$. It is also clear that EEG recording is sometimes prohibitively expensive. Other studies ${ }^{10 \sim 13)}$ on sleep have centered on the recording of body movements. The instruments necessary for recording body movements are cheap. Simplicity of treatment, and the fact that no electrodes are used indicate that body movements recorded are likely to give a more accurate assessment of the subject's usual sleep pattern. In this way it is possible to observe for long periods at a time, which is important when studying the comfort factors of mattresses. From these aspects, the most valid method of recording sleep for the purpose of studying mattress comfort is through body movements.

This study was conducted on the relation between the psychological factors of the feeling on awakening and body movements. I sought evidence on whether or not the measurement of various body movements was useful as an indicator of comfort.

\section{METHODS}

1. Subjects and experimental conditions

The experimental subjects were 21 healthy female volunteers, aged 19 to 31 yrs. The purpose of this study was to observe the subject's usual sleep pattern. All the subjects were told nothing about the experiment, which was done in the course of their daily routine with no control during the experiment. Three experiments were performed in this study. In Experiments I and II, each subject was monitored every night for 43 or 49 days and in Experiment III, 16 subjects were monitored 4 times once every 8 days (Table 1). Data recorded on a menstrual night or on a night when subjects were in poor physical condition were omitted, so each sample size is shown in Table 2 and Table 3 . The objectives of Experiments I and II were to study the subject's body movements as an indicator of comfort and Experiment III was to study the individual differences of body movements.

2. Recording methods of body movements

All-night recordings of body movements were conducted using two methods; the air-mattress method (Experiment I) and the cable method (Experiments II and III). The principle of the air-mattress 
Table 1 Summary of conditions in the three experiments.

\begin{tabular}{ccccccc}
\hline $\begin{array}{l}\text { Experiment } \\
\text { number }\end{array}$ & $\begin{array}{c}\text { Number of } \\
\text { subjects }\end{array}$ & $\begin{array}{c}\text { Age range } \\
\text { (yr.) }\end{array}$ & Sex & Date & $\begin{array}{c}\text { No. of nights } \\
\text { per subject }\end{array}$ & Place \\
\hline I & 1 & 31 & female & $\begin{array}{l}1980.1 .28- \\
1980.3 .10\end{array}$ & 43 & home \\
& \multirow{2}{*}{19} & $19-20$ & female & $\begin{array}{l}1982.10 .18- \\
1982.12 .12\end{array}$ & 49 & dormitory \\
II & \multirow{2}{*}{16} & $18-20$ & female & $\begin{array}{l}1981.6 .4 \\
1981.7 .5\end{array}$ & 4 & dormitory \\
\hline
\end{tabular}

method was that the air pressure of an air-mattress placed under the main mattress changed when a person moved. The air pressure was transmitted to a strain gauge through a hard rubber tube, then passed through an amplifier and was recorded. The principle of the cable method was that the static electricity occurring in a cable changed when a person moved. The variance of static capacity changed to the variance of potential difference, so the variance of potential difference was amplified and recorded. This method used a body movement sheet in which a cable was placed in the form of a coil. An interval of $20 \mathrm{cms}$ was allowed between each cable and the sheet placed under the mattress. The air-mattress method was an improvement on Sasaki's method ${ }^{14)}$ and the cable method was an improvement on Takahashi's method ${ }^{15}$. Each instrument was devised originally and specifically for this study. In the air-mattress method the air volume was very important and difficult to decide. Too much air changed the feeling of the mattress while too little would result in failure to make a recording. Moreover the surface of the air-mattress was a rubber material which could have affected the absorption and emission of perspiration. Because the absorption and emission of perspiration occurred primarily through the mattress. So in Experiments II and III the cable method was used. The recordings of body movements shown in Fig. 1 are indicative of the data obtained from each method. In each method, body movement was recorded as a spike. The following 4 points were taken into consideration for interpreting the data ; 1) If the spike was higher than $0.13 \mathrm{mv}$, it was regarded as a body movement. $0.13 \mathrm{mv}$ was chosen because this was the smallest potential that was readable with the naked eye. 2) Continuous body movements within a 30 -sec period were regarded as one body movement (Fig. 1-C). 3) A period of more than $10 \mathrm{~min}$ in sleep latency was regarded as indicating that the subject had fallen asleep ${ }^{16)}$, and the data were read after the subject fell asleep. 4) In order to omit the body movements due to awakening, data recording was maintained until 5 min before awakening. Ten sleep parameters were noted from data on body movements; Sleeping length, Sleep latency, Frequency of body movements per hour (FB), Mean rest period time (MR), Max. rest

A
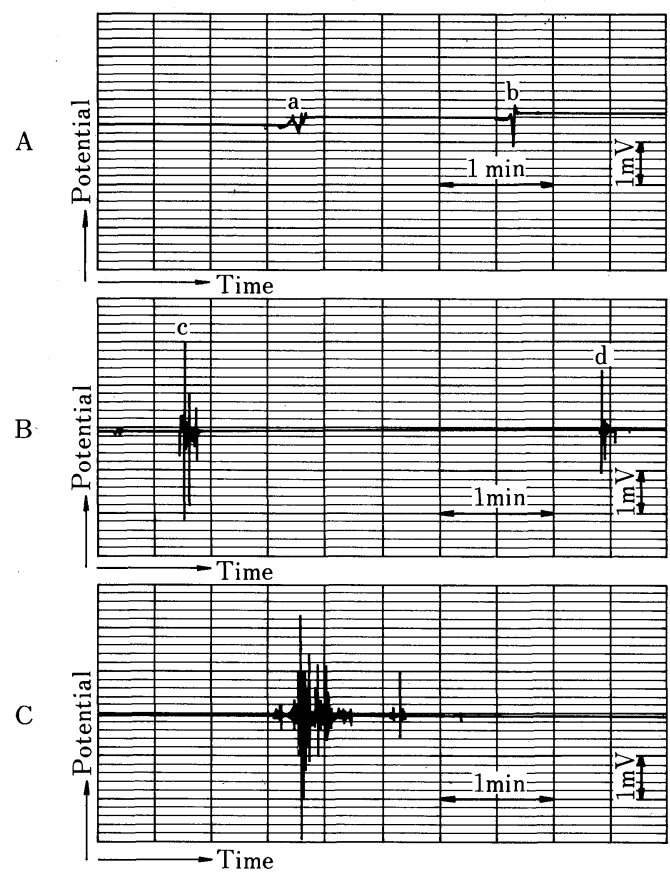

Fig. 1 Actual records of body movements. A : Air-mattress method, B : Cable method, C: Continuous body movements. a, b, c, d : Body movement; $\overline{\mathrm{ab}}$, $\overline{\mathrm{cd}}$ : Rest period. 
period time (MAR), Time spent MAR (TMAR), Frequency of body movements before MAR (FMAR), Mean rest period time during the first 1 hour of sleep, Rest period time just before awakening and Percentage of body movements.

3. Subjective reports

Each morning subjects were asked to fill out a brief questionnaire about their nights' sleep ; how long it took them to fall asleep initially, at what time they had fallen asleep and had finally woken, how often they had awoken during the night, and what caused each awakening. They rated the feeling on awakening on a 3-point scale ('comfortable' $=1$, to 'uncomfortable' $=3$ ).

4. Statistical analyses

In this study 'the feeling on awakening' was used as the dependent variable and 10 sleep parameters were used as the independent variables. In order to test the difference between 2 categories (comfortable and uncomfortable) on the dependent variable for each independent variable, the results were analysed by Analysis of variance, Student's $t$-test and Mann-Whitney $U$-test ${ }^{17)}$.

\section{RESULTS}

\section{Experiment I}

Table 2 shows the relation between the subject's feeling on awakening and the 10 sleep parameters. By using the Student's $t$-test only 5 parameters such as FB, MR, MAR, TMAR and FMAR showed a significant difference in the means of the 2 categories on the dependent variable -a comfortable feeling $(\mathrm{CF})$ and an uncomfortable feeling (UF). The mean of FB was recorded at 4.3 movements which indicated $\mathrm{CF}$ and at 5.5 movements which indicated UF, therefore FB increased significantly from $\mathrm{CF}$ to $\mathrm{UF}(t: p<0.01)$. The mean of MR was recorded at $13.2 \mathrm{~min}$ which indicated $\mathrm{CF}$ and at $10.5 \mathrm{~min}$ which indicated UF, therefore MR decreased significantly from CF to UF $(t: p<0.01)$. MAR was recorded at $73.0 \mathrm{~min}$ which indicated $\mathrm{CF}$ and at $44.8 \mathrm{~min}$ which indicated UF, therefore MAR decreased significantly from CF to UF $(t: p<0.01)$. The mean of TMAR was recorded at $5.3 \mathrm{~min}$ which indicated $\mathrm{CF}$ and at 114.4 min which indicated UF, therefore TMAR increased significantly from CF to UF $(t: p<0.05)$. The

Table 2 Sleep parameters \& feeling on awakening (Exp. I).

\begin{tabular}{|c|c|c|c|c|c|c|c|}
\hline \multirow[b]{2}{*}{ Parameter } & \multicolumn{2}{|c|}{$\begin{array}{c}\text { Comfortable(a) } \\
\qquad N=4\end{array}$} & \multicolumn{2}{|c|}{$\begin{array}{l}\text { Normal (b) } \\
N=21\end{array}$} & \multicolumn{2}{|c|}{$\begin{array}{c}\text { Uncomfortable(c) } \\
\qquad N=9\end{array}$} & \multirow{2}{*}{$\begin{array}{c}\text { Significance } \\
\qquad a-c\end{array}$} \\
\hline & Mean & S.D. & Mean & S.D. & Mean & S.D. & \\
\hline Sleeping length (min) & 448 & 52.29 & 404.4 & 36.65 & 426.3 & 33.63 & \\
\hline Sleep latency (min) & 7.7 & 7.47 & 8.8 & 8.47 & 6.1 & 6.15 & \\
\hline $\begin{array}{l}\text { Frequency of body movements } \\
\text { per hour (movements) : FB }\end{array}$ & 4.3 & 0.54 & 5.1 & 1.07 & 5.5 & 0.56 & $\begin{aligned} t & : p<0.01 \\
U & : p<0.01\end{aligned}$ \\
\hline $\begin{array}{l}\text { Mean rest period } \\
\text { time }(\min ): \text { MR }\end{array}$ & 13.2 & 1.71 & 11.7 & 2.60 & 10.5 & 1.17 & $\begin{array}{l}t: p<0.01 \\
U: p<0.05\end{array}$ \\
\hline $\begin{array}{l}\text { Max. rest period } \\
\text { time }(\min ): \text { MAR }\end{array}$ & 73.0 & 19.49 & 53.3 & 10.13 & 44.8 & 9.40 & $\begin{array}{l}t: p<0.01 \\
U: p<0.05\end{array}$ \\
\hline $\begin{array}{l}\text { Time spent max. rest } \\
\text { period time }(\mathrm{min}): \text { TMAR }\end{array}$ & 5.3 & 6.40 & 51.4 & 57.40 & 114.4 & 122.63 & $\begin{array}{l}\mathrm{F}: p<0.01 \\
t: p<0.05\end{array}$ \\
\hline $\begin{array}{l}\text { Frequency of body movements } \\
\text { before max. rest period } \\
\text { time (movements): FMAR }\end{array}$ & 1.3 & 1.26 & 5.8 & 5.88 & 9.6 & 8.73 & $\begin{array}{l}\mathrm{F}: p<0.01 \\
t: p<0.05\end{array}$ \\
\hline $\begin{array}{l}\text { Mean rest period time } \\
\text { during the first } 1 \\
\text { hour of sleep }(\mathrm{min})\end{array}$ & 31.3 & 20.16 & 16.8 & 7.37 & 22.4 & 16.01 & \\
\hline $\begin{array}{l}\text { Rest period time just } \\
\text { before awakening ( } \min \text { ) }\end{array}$ & 1.8 & 0.75 & 5.1 & 6.14 & 4.8 & 7.77 & \\
\hline $\begin{array}{l}\text { Percentage of body } \\
\text { movements (\%) }\end{array}$ & 2.6 & 0.81 & 3.5 & 1.34 & 3.5 & 1.38 & \\
\hline
\end{tabular}


data variance of TMAR indicating $\mathrm{CF}$ was less than that indicating UF $(\mathrm{F}: p<0.01)$. The mean of FMAR was recorded at 1.3 movements which indicated $\mathrm{CF}$ and at 9.6 movements which indicated UF, therefore FMAR increased significantly from CF to UF $(t: p<0.05)$. The data variance of FMAR indicating CF was less than that indicating UF ( F : $p<0.01$ ). The Student's $t$-test requires normality of distribution and homogeneity of variance for the groups under study. In this study, the sample size in the 'comfortable' category was small and it was uncertain whether the distribution was normal or not. So the Mann-Whitney $U$-test was also used. The Mann-Whitney $U$-test is a nonparametric test and is especially useful with small samples. By using $U$-test only 3 parameters such as FB, MR and MAR showed a significant difference in the ranks of the 2 categories on the dependent variable. The data suggest that FB increased significantly from $\mathrm{CF}$ to UF $(U: p<0.01)$, MR and MAR decreased significantly from $\mathrm{CF}$ to UF $(U: p<0.05)$.

Fig. 2 shows the mean rest period time per hour of spontaneous sleep. For a comfortable feeling on awakening the max. peak was observed during the early sleep period and for an uncomfortable feeling

Table 3 Sleep parameters \& feeling on awakening (Exp. II).

\begin{tabular}{|c|c|c|c|c|c|c|c|c|}
\hline \multirow{2}{*}{ Parameter } & \multirow{2}{*}{ Subject } & \multicolumn{2}{|c|}{ Comfortable (a) } & \multicolumn{2}{|c|}{ Normal (b) } & \multicolumn{2}{|c|}{ Uncomfortable(c) } & \multirow{2}{*}{$\begin{array}{c}\text { Significance } \\
\mathrm{a}-\mathrm{c} \\
\end{array}$} \\
\hline & & $\left(\mathrm{N}^{*}\right)$ Mean & S.D. & $\left(\mathrm{N}^{*}\right)$ Mean & S.D. & $\left(\mathrm{N}^{*}\right)$ Mean & S.D. & \\
\hline \multirow{4}{*}{ FB(mov.) } & A & (3) 3.5 & 3.01 & (18) 4.9 & 2.14 & (13) 5.3 & 2.17 & \multirow[b]{2}{*}{$\begin{aligned} t: & p<0.01 \\
U: & p<0.05\end{aligned}$} \\
\hline & B & (4) 2.3 & 0.70 & (16) 2.7 & 1.08 & (14) 5.0 & 1.35 & \\
\hline & $\mathrm{C}$ & (3) 6.2 & 0.58 & (14) 8.7 & 2.39 & ( 4) 9.3 & 1.28 & $t: p<0.05$ \\
\hline & $\mathrm{D}$ & (6) 2.2 & 1.25 & (19) 3.9 & 1.31 & (10) 4.1 & 1.24 & $\begin{aligned} t: & p<0.05 \\
U & : p<0.05\end{aligned}$ \\
\hline \multirow{4}{*}{$\mathrm{MR}(\min )$} & A & 17.0 & 2.31 & 13.4 & 5.48 & 15.1 & 2.36 & \multirow{4}{*}{$\begin{array}{r}t: p<0.05 \\
U: p<0.05 \\
t: p<0.05 \\
t: p<0.01 \\
U: p<0.05\end{array}$} \\
\hline & B & 28.3 & 2.35 & 27.5 & 4.45 & 23.7 & 3.26 & \\
\hline & $\mathrm{C}$ & 14.8 & 2.90 & 8.3 & 1.70 & 8.5 & 2.46 & \\
\hline & $\mathrm{D}$ & 40.1 & 22.5 & 15.8 & 4.72 & 17.0 & 3.89 & \\
\hline \multirow{4}{*}{ MAR (min) } & A & 76.2 & 13.21 & 55.0 & 17.14 & 46.9 & 10.43 & $\begin{aligned} t: & p<0.01 \\
U & : p<0.05\end{aligned}$ \\
\hline & B & 96.0 & 22.77 & 93.4 & 40.98 & 66.5 & 22.98 & $\begin{array}{r}t: p<0.05 \\
U: p<0.05\end{array}$ \\
\hline & $\mathrm{C}$ & 65.2 & 14.25 & 55.4 & 17.76 & 24.6 & 3.32 & $\begin{aligned} \mathrm{F}: & p<0.05 \\
t: & p<0.01\end{aligned}$ \\
\hline & $\mathrm{D}$ & 98.6 & 25.30 & 63.1 & 18.36 & 76.6 & 23.09 & $\begin{aligned} & t: p<0.05 \\
& U: p<0.05\end{aligned}$ \\
\hline \multirow{4}{*}{ TMAR (min) } & A & 59.2 & 54.39 & 124.8 & 83.08 & 224.95 & 95.81 & $\begin{aligned} t: p<0.05 \\
U: p<0.05\end{aligned}$ \\
\hline & B. & 70.5 & 80.76 & 103.9 & 87.42 & 105.8 & 105.82 & \multirow{3}{*}{$\begin{aligned} t: & p<0.05 \\
U: & p<0.05\end{aligned}$} \\
\hline & $\mathrm{C}$ & 34.0 & 52.38 & 91.4 & 77.57 & 116.98 & 22.17 & \\
\hline & $\mathrm{D}$ & 92.6 & 79.15 & 165.2 & 97.47 & 186.48 & 138.72 & \\
\hline \multirow{4}{*}{ FMAR (mov.) } & A & 5.5 & 5.67 & 10.5 & 8.36 & 13.5 & 10.61 & \multirow[b]{4}{*}{$\mathrm{F}: p<0.01$} \\
\hline & B & 3.8 & 4.86 & 6.3 & 6.90 & 6.6 & 5.72 & \\
\hline & $\mathrm{C}$ & 6.5 & 0.71 & 10.6 & 10.78 & 12.3 & 6.22 & \\
\hline & $\mathrm{D}$ & 5.0 & 4.35 & 11.6 & 9.70 & 13.7 & 11.48 & \\
\hline
\end{tabular}

*: Sample size. 


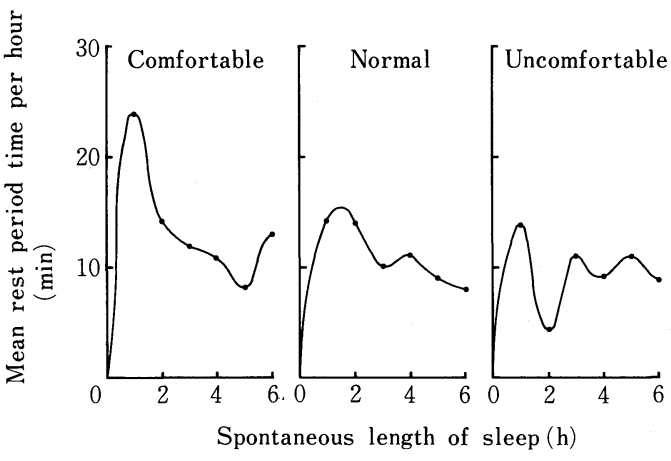

Fig. 2 Mean rest period time per hour on 3 different feelings on awakening.

Table 4 Analysis of variance, mean scores and standard deviations for each parameter (Exp. III).

\begin{tabular}{llrr}
\hline \multicolumn{1}{c}{ Parameter } & \multicolumn{1}{c}{ ANOVA } & Mean & S.D. \\
\hline FB(mov.) & $\mathrm{F}=5.13(p<0.01)$ & & \\
MR (min) & $\mathrm{F}=2.51(p<0.01)$ & & \\
MAR(min) & $\mathrm{F}=1.28$ & 70.7 & 15.14 \\
TMAR(min) & $\mathrm{F}=0.50$ & 167.3 & 103.29 \\
FMAR (mov.) & $\mathrm{F}=0.88$ & 10.5 & 6.50 \\
\hline
\end{tabular}

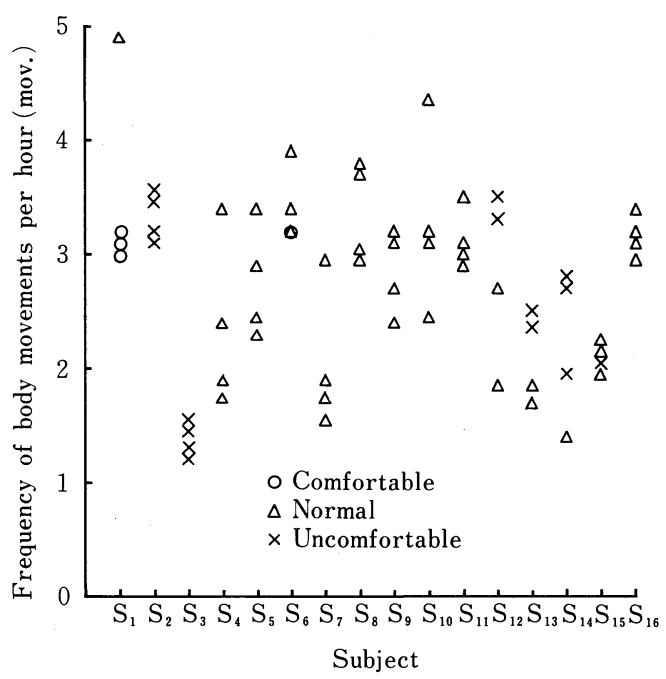

Fig. 3 Frequency of body movements per hour on each subject in Experiment III.

several peaks were observed during the sleep period.

2. Experiment II

Experiment I clearly showed that the feeling on awakening had a direct connection with the 5 sleep parameters, so in Experiment II the data was analyzed using only these 5 parameters (Table 3). Both FB and MR showed the same tendency as the results in Experiment I (FB increased and MR decreased from $\mathrm{CF}$ to UF), but the data for Subject A did not show any significant change. MAR showed the same tendency as the result in Experiment I (MAR decreased from CF to UF). Both TMAR and FMAR showed the same tendencies as the result in Experiment I (both TMAR and FMAR increased from CF to UF). But the data of TMAR for Subjects B and D, and the data of FMAR for 4 subjects did not show any significant change.

3. Experiment III

The results were shown in Table 4. FB and MR clearly showed the individual's different reactions but MAR, TMAR and FMAR did not show any significant change in the individual's reactions. That is, in the group of female students aged $18-20 \mathrm{yrs}, 3$ parameters (MAR, TMAR and FMAR) out of the 5 investigated went for the most part unchanged. The average recording time for MAR was.70.7 min, that for TMAR was 167.3 min and the FMAR was 10.5 movements.

Fig. 3 shows FB on each subject. The data of the 16 subjects was clearly divided into 2 groups; the data variance was minimal for Subjects $\mathrm{S}_{2}, \mathrm{~S}_{3}, \mathrm{~S}_{15}$ and $\mathrm{S}_{16}$ while on the other hand, it was quite large for Subjects $\mathrm{S}_{4}, \mathrm{~S}_{7}$ and $\mathrm{S}_{10}$. Ten subjects had similar reactions during the experiment.

\section{DISCUSSION}

Many papers have been published concerning body movements during sleep since Szymanski ${ }^{18)}$ wrote the first paper in 1914. In those papers ${ }^{3,10 \sim 13)}$ body movements were defined and the phenomenon of body movement was mainly dealt with from the standpoint of the depth of sleep, that is, in a period of deep 
sleep, few body movements were observed. On the other hand, monitoring the feeling of the subject on awakening is another valid method which shows whether the sleep quality was good or not and what effect it may have on the subject's ability to function during the day. The feeling on awakening is a very important factor to consider when monitoring sleep. There are, however, very few papers which have included this aspect. Therefore the relation between sleep quality and the feeling on awakening is still unknown.

The objective of this study was to investigate whether the feeling on awakening could be predicted by measuring body movements. Two important results were obtained. First, in the experiment where 5 subjects were monitored over the course of several nights, the data clearly shows that the feeling on awakening was directly related to 5 sleep parameters-FB, MR, MAR, TMAR and FMAR-which were disclosed by measuring body movements. Three of these parameters-FB, MR and MAR in particular, showed a significant difference between 2 categories of the feeling on awakening. (The data for Subject A was an exception, as both FB and MR were unclear. However the relation between that subject's feeling and body movements were very distinct, so the data was dealt with in the same manner as the data from the other 4 subjects.) Second, in the experiment where 16 subjects were monitored once every 8 days, it was clear that both FB and MR showed the individual's different reactions and that MAR, TMAR and FMAR, on the other hand, showed no remarkable reaction at all. Though FB and MR are both physical properties, in the case of one person FB and MR showed a clear relation with the psychological aspects of sleep, that is, when there was a comfortable feeling on awakening FB was minor and MR was longer. Yanase et al. ${ }^{19)}$ reported that a person whose weight was below average did not move very often during sleep because the blood vessels were not suppressed. In this study it was thought that differences in subjects' physical condition affected the individual's body movements, so that FB and MR showed the individual's reactions. Further studies are necessary before drawing definite conclusions on this problem. MAR, TMAR and FMAR showed no remarkable variance in reaction which made it clear that these 3 parameters were not significant factors for this group of female students. Both TMAR and FMAR measured the existence of MAR. If MAR was observed in the early stages of sleep, the data of these 2 parameters showed minor variance, while on the other hand if MAR was observed in the later stages of sleep, the data showed considerable variance. Jovanovic ${ }^{12,20)}$ reported that 2 types of sleep existed in the normal person ; morning type and evening type. A person whose pattern of sleep falls within the morning type is said to be energetic in the morning and a person whose pattern falls within the evening type is said to be energetic in the evening. In this study all the subjects were students, so the morning type was desirable for them. In fact the results of TMAR and FMAR showed minor variances. On the other hand, in the case of a person who works in the evening or night, the evening type is desirable for the person. Thus the type and depth of sleep directly effect human daily routine. Sleep type is an individual problem, therefore it could be stated that TMAR and FMAR were not universal as an indicator of comfort.

Consequently FB, MR and MAR appear to be the best parameters as indicators of the feeling on awakening, that is, comfort. Subjective assessment of comfort can be made objectively using these 3 parameters. It can be said that a comfortable feeling on awakening occurs when FB is minor and both $\mathrm{MR}$ and MAR are longer. It is possible, therefore, to gain objective data concerning comfort using the 3 parameters during a defined term. When considering the evaluation of a mattress using these 3 parameters, an experimental design, such as the latin square design, is necessary so that it has no effect on the individual's sleep pattern. After an experimental design is developed, it could be used to make a comparative study on various mattresses using the 3 parameters, which could be a great advantage to the manufacturers.

\section{CONCLUSIONS}

This study was conducted in order to make a distinct relation between the psychological factors and the physical aspects of sleep. The following results were obtained:

1) The feeling on awakening was distinctly related to 5 sleep parameters such as FB, MR, MAR, TMAR and FMAR, and for a comfortable feeling on awakening FB was minor, both MR and MAR were longer, 
TMAR was shorter and FMAR was minor.

2) By using the Student's $t$-test and the Mann-Whitney $U$-test, FB, MR and MAR showed a significant difference between a comfortable feeling and an uncomfortable feeling.

3) Both TMAR and FMAR were connected with the existence of MAR and were affected by sleep type. Sleep type is an individual problem, therefore these 2 parameters are not universal as an indicator of comfort.

4) FB and MR showed the individual's reactions, and MAR, TMAR and FMAR showed no remarkable reaction.

5) Consequently FB, MR and MAR are the best parameters to use as an indicator of comfort, and after an experimental design which in no way interrupts the individual's sleep pattern is developed, a comparative study on various mattresses can be conducted.

Acknowledgments : I wish to thank Professor, Dr. H. Okuda and Assistant professor, Dr. N. Tsubota, Department of Hygiene, School of Medicine, Hiroshima University, for their kind advices and assistances on the analyses of the data obtained.

This study was supported in part by a Grant in Aid of Scientific Research from the Ministry of Education.

\section{REFERENCES}

1) Belart, W.: Matratzen, Merkblätt zur Rhema-Prophylaxe, Nr. 11, Schweiz. Rheumaliga, Zürich (1970).

2) Grandjean, E.: The physiological design of household furniture in "Ergonomics of the Home" (Editor: P.R. Davis), p. 136-138, Taylar \& Francis Ltd., London (1973).

3) Okuma, T.: Sleep-Physiology and Clinical Problems-(in Japanese), Igaku Shoin Ltd., Tokyo (1977).

4) Jovanovic, U.: The Nature of Sleep, Gustav Fischer Verlag, Stuttgart (1973).

5) Dement, W.: Some must watch while some must sleep (in Japanese, Translator: Okuma, T.), Misuzu Shobo, Tokyo (1976).

6) Vernon, J.: Inside the black room (in Japanese, Translator: Okuma, T.), Misuzu Shobo, Tokyo (1977).

7) Ueda, H., Shimazono, Y., Takeuchi, J. and Toyokura, Y.: Sleep Disorders (in Japanese), Nankodo, Tokyo (1982).

8) Johns, M. and Doré, C. : Sleep at Home and in the Sleep Laboratory: Disturbance by Recording Procedures, Ergonomics, 21, 325-330 (1978).

9) Coble, P., McPartland, R., Silva, W. and Kupfer, D. : Is There a First Night Effect ?, Biological Psychiatry, 9, 215-219 (1974).

10) Snyder, F., Hobson, J., Morrison, D. and Goldfrank, F. : Changes in respiration, heart rate and systolic blood pressure in human sleep, J. appl. Physiol., 19, 417-422 (1964).

11) Dement, W. and Kleitman, N.: Cyclic variations in EEG during sleep and their relation to eye movements, body motility, and dreaming, EEG clin., Neurophysiol., 9, 673-690 (1957).

12) Jovanovic, U.: Normal sleep in man, An experimental contribution to our knowlege of the phenomenology of sleep, Hippokrates, Stuttgart (1971).

13) Kanz, E. und Gertis, W.: Schlaftiefemessungen an verschiedenen Polsterwaren, Bekleidungsmedizin, 4, 6-14 (1964).

14) Sasaki, C. and Hanaoka, T.: The Actographic Study on the Body Movement during Natural Sleep (in Japanese), Home Economics Research Journal of Nara Women's University, 10, 54-65 (1963).

15) Takahashi, S.: Simple body movement device (in Japanese), Japanese journal of electroencephalography and electromyography, 5, 149-152 (1977).

16) Yanase, T., Matsumoto, T., Morita, Y. and Hanaoka, T.: Studies on the Natural Sleep, (1) On the relationship between body movement and electroencephalography, (2) On the effects of sun beams upon sleeping in morning (in Japanese), Home Economics Research Journal of Nara Women's University, 15, 55-64 (1968).

17) Rosco, T. J.: The Mann-Whitney U-test in "Fundamental research statistics for the behavioral science, Second edition" (Editor: I. Olkin), p. 230-237, Holt, Rinehart and Winston, INC., New York (1975).

18) Szymanski, J. : Eine Methode zur Untersuchung der Ruhe und Aktivitats-Perioden bei Tieren, Pflugers Arch., 158, 343-385 (1914). 
19) Yanase, T., Abe, F., Kitazawa M., Suzumura, M., Miki, S., Matsumoto, T. and Hanaoka, T. : Studies on the Natural Sleep, (3) On the Types of Individual Difference Body Movement during Sleep (in Japanese), Home Economics Research Journal of Nara Women's University, 15, 175-184 (1968).

20) Jovanović, U. : Schlaf und Traum, Gustav Fischer Verlag, Stuttgart (1974).

\section{快適性の指標としての睡眠中の体動について}

広島大学医学部衛生学教室

楠幹 江

寝具の快適性を追求する指標を得るため，簡易で規制の少ない体動計を用いて自然な睡眠を記録し，種々の体動測定 項目とめざめ感の良否との関係を検討したところ，次のような成績が得られた。1）めざめ感の良否は，5種の体動測 定項目 -1 時間あたりの体動数 (FB), 平均静止時間 (MR), 最大静止時間 (MAR), 最大静止時間までの所要時間 (TMAR)，最大静止時間までの体動回数 (FMAR) 一と関連があり，めざめ感が快適な時，FB は少なく，MR，MAR は長く, TMAR は短く, FMAR は少ない, 結果となった。2） 5 種の体動測定項目のうち, FB, MR, MAR は, め ざめ感の良否と有意な相関を示す傾向がみられたが, TMAR, FMAR は, MAR の出現時期と関係があるため, 指標と することは困難と思われる。3 )FB, MR は個人差が示されたが, MAR, TMAR, FMAR は個人差は示されなかった。 4 ) 以上の結果, “めざめ感の良い寝具”を検討する際の指標としては, FB, MR, MARが最適であり, 個人差の影響 を消す実験計画をたてた上で，各種寝具を比較検討することは意味があると思われる。

Key words : Body movements, Feeling on awakening, Mattresses, Indicator of comfort,

Sleep

体動, めざめ感, 寝具, 快適性の指標, 睡眠 